\title{
Is Death Different? Two Ways Law Can Fail
}

\begin{abstract}
This chapter describes how capital cases are handled in Japan and the United States - the two largest developed democracies that retain capital punishment and continue to carry out executions on a regular basis. The comparison shows that death penalty law can fail in two ways. In the United States, where the Supreme Court has ruled that "death is different," law fails by not fulfilling many of its promises to provide special procedures and protections for capital defendants. In Japan, by contrast, law fails by not making many promises at all.
\end{abstract}

Keywords Capital jurisprudence - Death is different • Super due process $\cdot$ Factual accuracy $\cdot$ Moral accuracy $\cdot$ Legal failure

Despite frequent claims by Japanese officials to the contrary, Japan is not "careful" about how it administers capital punishment. In Japan, potentially capital cases are treated much the same as less serious cases. Yet if "a single life weighs more than the entire earth," as Japan's Supreme Court asserted in a 1948 decision upholding the constitutionality of capital punishment, then why doesn't Japanese criminal procedure reflect this reality?

This chapter describes how death penalty cases are treated in Japan and the United States, the two most prominent developed democracies that retain capital punishment and continue to use it on a regular basis.

(C) The Author(s) 2020

D. T. Johnson, The Culture of Capital Punishment in Japan, Palgrave Advances in Criminology and Criminal Justice in Asia, https://doi.org/10.1007/978-3-030-32086-7_2 
The comparison shows that the law can fail in two ways. In the United States, law fails by not fulfilling many of its promises to provide special procedures and protections for defendants in capital cases. In Japan, law fails by not making any promises at all.

\section{Is Japan Careful About Capital Punishment?}

In the murder trial of Tateyama Tatsumi that took place in Chiba District Court in 2011, defense lawyers made two extraordinary appeals to the three professional judges and six lay judges who decided whether Tateyama should be condemned to death for the offenses-including one murder-that he committed during a two-month rampage which started two weeks after he was released from Tsukigata prison in Hokkaido, where he had served a seven-year sentence for robbery. On the first day of this trial, defense lawyer Urazaki Hiroyasu began his opening argument by telling the court that this would probably be a capital trial and that the people sitting in judgment should therefore pay careful attention to the proceedings which would follow. "The death penalty is an extremely severe punishment," Urazaki observed. "It ought to be used carefully, and it should only be imposed if it cannot possibly be avoided."

Two weeks later, on the last day of Tateyama's trial and a few minutes after prosecutors had stated for the first time that they wanted Tateyama sentenced to death, defense lawyer Murai Hiroaki asked the court to impose a capital sentence if and only if everyone on the panel agreed that death was the appropriate penalty. Under Japan's lay judge law, five votes are enough to convict a defendant and sentence him or her to death, a decision rule that Tateyama's defense team believed was insufficiently cautious. "The death penalty must be administered very carefully," Murai implored the court. "If you cannot reach a consensus, then please do not impose the ultimate penalty."

Urazaki's prediction proved prescient, and Murai's request was ignored. During the press conference following the trial session where Tateyama was sentenced to death, one lay judge wondered: "Is this really the right thing to do? I still have doubts" (honto ni kore de yokatta no $k a$ ? mada gimon o motte iru). But before he could describe the nature of his misgivings, this lay judge was stopped by a clerk of the court who had been assigned the role of enforcing the confidentiality clause of the Lay Judge Law, which allows dissent only if it remains secret. A similar but unwritten rule discourages dissent on Japan's Supreme Court when 
it finalizes a sentence of death. ${ }^{1}$ The net effect of these policies of secrecy and silence is to dissuade public discussion about the gravest decision a government can make.

The arguments by Tateyama's defense lawyers were meant to encourage the Chiba court to be careful about employing death as a punishment. In the United States their requests would have been unnecessary because American prosecutors are required to tell defense lawyers and the court-long before a trial starts-whether they intend to seek a sentence of death, and because the decision rule in American capital trials is consensus: if even 1 juror out of 12 considers a capital sentence inappropriate, the defendant cannot be condemned to death.

In Japan, everyone associated with capital punishment-prosecutors, judges, lay judges, defense lawyers, Ministers of Justice, the media, politicians, and victims and survivors-acknowledges that life-and-death decisions should be made as "carefully" as possible (shincho ni), but the institutional and procedural reality is that capital cases are treated much the same as other criminal cases. In reality, death is not different in Japan.

\section{“Death Is Different” in the United States}

Since the 1970s, the U.S. Supreme Court has held that "death is different" from other criminal punishments in two respects. First, death is different in its severity and enormity, for as "the ultimate punishment" it denies the offender's humanity and the possibility of his or her reform. In addition, death is different because the finality of execution makes the consequences of error irreversible. The recognition that death is different in these ways has generated an array of special procedural protections for capital defendants. Most fundamentally, ordinary due process is not enough; there must be "super due process" (and international human rights law proceeds from a similar premise).

Super due process has five implications in American criminal procedure. $^{2}$ First, capital trials must be carried out in separate stages: first determining the guilt of a defendant, and then (if the defendant has

\footnotetext{
${ }^{1}$ Yamaguchi Susumu and Miyaji Yu, Saikosai no Anto: Shoswiken ga Jidai o Kiribiraku (Asahi, 2011), p. 51.

${ }^{2}$ Robert M. Bohm, Ultimate Sanction: Understanding the Death Penalty Through Its Many Voices and Many Sides (Kaplan Publishing, 2010), pp. vi-ix.
} 
been convicted) deciding the sentence. Second, capital juries must be given direction in the form of "aggravating and mitigating factors" to help guide their discretion at the sentencing stage. Third, after a death sentence has been imposed it receives an automatic appellate review, regardless of the defendant's wishes. In some American jurisdictions, defendants who have been sentenced to death cannot waive their right to appeal, as approximately one-third of death-sentenced defendants in Japan do. Fourth, American appellate courts engage in proportionality review in order to identify inappropriate disparities in sentencing practice. The principle underlying this practice is that like cases should be treated alike, and different cases differently. Finally, in order to impose a capital sentence, all 12 jurors must agree that death is the appropriate sanction. For the defense this means that a sentence of death can be prevented by convincing just one juror to oppose it. Clarence Darrow, one of the most highly esteemed defense lawyers in American history, defended more than 100 persons in capital trials, and not a single one was sentenced to death. ${ }^{3}$ But if Darrow had faced a majority rule like the one that prevails in Japan, he probably would have had a different record.

Although American law promises super due process, it often fails to deliver. ${ }^{4}$ A classic study of error rates in American capital cases found that serious error-error substantially undermining the reliability of capital verdicts-had reached "epidemic proportions" in America's death penalty system. In this analysis, the "overall error rate" was defined as the proportion of fully reviewed capital judgments that were overturned on appeal due to serious error between 1973 and 1995. By this definition, the overall error rate was 68 percent, which means that approximately two out of every three capital sentences reviewed by appellate courts were reversed because they were found to be seriously flawed..$^{5}$ As of 2017 , only 15 percent of all death

${ }^{3}$ John A. Farrell, Clarence Darrow: Attorney for the Damned (Vintage Books, 2011).

${ }^{4}$ Carol S. Steiker and Jordan M. Steiker, Courting Death: The Supreme Court and Capital Punishment (The Belknap Press of Harvard University Press, 2016), especially Chapter 5 ("The Failures of Regulation").

${ }^{5}$ James S. Liebman, Jeffrey Fagan, and Valerie West, "A Broken System: Error Rates in Capital Cases, 1973-1995”, https://papers.ssrn.com/sol3/papers.cfm?abstract_id=232712. 
sentences imposed by American trial courts since 1977 had resulted in execution. By state, the range runs from less than 1 percent in Pennsylvania to more than 70 percent in Virginia. The most common errors in American death penalty trials include police and prosecutors who suppressed exculpatory evidence or committed other professional misconduct, incompetent defense lawyers, jurors who were misinformed about the law, and biased judges and jurors. When America's appellate courts find serious error, more than 8 out of every 10 cases sent back for retrial end in a sentence less than death - and 9 percent end in acquittal. The fundamental cause of all of this error is overuse. "The more often officials use the death penalty," a subsequent study concluded, "the greater the risk that capital convictions and sentences will be seriously flawed." 6

It is widely believed that Japan uses capital punishment less frequently than the United States, but this view is mistaken. In per capita terms (executions per million population), Japan's execution rate has long been lower than that for the United States, and it has been much lower than the rates in high-rate American states such as Texas and Virginia. But the per capita rate of execution is a poor measure of frequency of use because (Stalinist nightmares aside) persons are not selected randomly for death; they are condemned and executed from a larger pool of potentially capital cases. In the United States and Japan, this pool consists entirely of homicide crimes. Hence, to assess the scale of capital punishment in a country, one must consider the size of the relevant capital-crime pool. In the United States, about 2 percent of all known murder offenders are sentenced to death, though this figure varies by state, from around 0.4 percent in Colorado to 6 percent or so in Nevada. The probability of a known murderer being sentenced to death in Japan is not much different than in many American jurisdictions. From 1994 through 2003, the chance of a Japanese murderer being sentenced to death was 1.3 percent-about the same rate as in the American states of California and Virginia. And in 2007, when Japan had 14 death sentences in courts of

${ }^{6} J a m e s$ S. Liebman, Jeffrey Fagan, Andrew Gelman, Valerie West, Garth Davies, and Alexander Kiss, "A Broken System, Part II: Why There Is So Much Error in Capital Cases, and What Can Be Done About It", http://www2 law.columbia.edu/brokensystem2/index2 .html. 
original jurisdiction and the United States had 110, the ratio of death sentences to homicides was actually higher in Japan than in the United States. By measures such as these, Japan is not "careful" in its use of capital punishment. It is a vigorous killing state, on par with some of the most aggressive death penalty states in America. ${ }^{7}$

\section{Death Is Not Different in Japan}

Japanese officials claim to administer capital punishment carefully and cautiously, but reality contradicts their claims. For starters, Japanese law makes no promise of super due process. More specifically, there are at least 12 ways in which death is not different in Japan. ${ }^{8}$ The net result is a legal system that is careless about capital punishment.

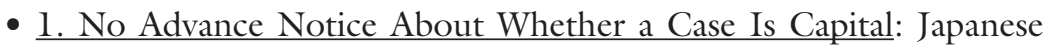
prosecutors make no advance announcement as to whether they will seek a sentence of death. The disclosure is only made on the penultimate day of trial, after all the evidence has been presented and just before the defense makes its closing argument. This non-disclosure policy makes it difficult for Japanese bar associations to provide institutional support of the kind that many American capital defenders take for granted. The non-disclosure policy also means that while Japan has a system of capital punishment, it does not really

${ }^{7}$ David T. Johnson, “American Capital Punishment in Comparative Perspective”, Law \& Social Inquiry, Vol. 36, No. 4 (Fall 2011), p. 1052.

${ }^{8}$ David T. Johnson, "Progress and Problems in Japanese Capital Punishment", in Roger Hood and Surya Deva, editors, Confronting Capital Punishment in Asia: Human Rights, Politics, and Public Opinion (Oxford University Press, 2013), pp. 175-180. In addition to the 12 problems summarized in the text, Japan has not signed several international treaties related to capital punishment, including the Second Optional Protocol to the International Covenant on Civil and Political Rights, which was created by the United Nations in 1989 and has been ratified by more than 70 nations, and it has not established the punishment of life without parole. All American states that retain capital punishment provide for the penalty of life without parole, as do America's federal and military justice systems. Life without parole would give judges and lay judges in Japan a harsh sentencing option between life with the possibility of parole and the penalty of death. Its availability in America is one reason why death sentences and executions have dropped sharply since 2000 . 
have "capital trials" because, until a trial ends, nobody but the prosecutors know whether the defendant's life is at stake.

- 2. No Separate Stage for Sentencing: Capital trials in Japan are not bifurcated into separate guilt and sentencing phases, even when the defendant denies guilt, as defendant Ino Kazuo did in a murder trial in Tokyo in 2011. Ino was ultimately sentenced to death by a lay judge panel that learned almost nothing about what kind of person the 60-year-old defendant was, or what kind of life he had lived. For a system that purports to value "precise" decision-making (seimitsu shibo) as one foundation for its criminal process, this is a peculiar way to make judgments about life and death. In the murder trial of Tateyama Tatsumi in Chiba, the Chief Judge did not even allow an expert witness to appear for the defense to testify about one of the central issues in the trial: whether Tateyama has a cognitive and developmental disorder. The Chief Judge ruled in the pretrial process that such testimony would confuse the lay judges.

- $\underline{3}$. Victims' Demands for Punishment Distort Fact-Finding: Since capital trials are not bifurcated in Japan, victims and survivors are allowed during the fact-finding procedure to make statements about what punishment they want. This is a dangerous practice for two reasons: because research shows that courts are more likely to convict defendants if they are permitted to hear punitive sentencing requests, and because victims' wishes about punishment are supposed to be irrelevant with respect to the question of guilt. There is no principled way to justify this practice, and in fact the Code of Criminal Procedure gives judges ample discretion to prevent it from happening. Yet Japanese judges routinely allow it to occur. The Victim Participation System, which expands the rights and amplifies the voices of victims and survivors, also raises the risk that emotional demands for harsh punishment will distort truth-finding at trial (see Chapter 5). ${ }^{10}$ In the murder trial of Ino Kazuo in Tokyo, the victim's bereaved son was

\footnotetext{
${ }^{9}$ David T. Johnson, “Capital Punishment without Capital Trials in Japan's Lay Judge System", The Asia-Pacific Journal/Japan Focus, Vol. 7 (March 16, 2009), pp. 1-40, at https://apjjf.org/-David-T.-Johnson/3461/article.html.

${ }^{10}$ David T. Johnson, "Does Capital Punishment Bring Closure to Victims?", in Ivan Simonovic, editor, Death Penalty and the Victims (United Nations, 2016), pp. 75-82.
} 
permitted to state that he wanted the defendant sentenced to deathand this was on the second day of trial, when fact-finding had barely begun. In the murder trial of Tateyama Tatsumi in Chiba, two surviving parents, their attorney, four victims, and two prosecutors- 9 people in all-spent 195 minutes in the final trial session demanding that Tateyama be sentenced to death. The allotted time for the defense's closing argument was 60 minutes.

- 4. Simple Scripts and Rough Justice: The lay judge system which took effect in 2009 has reduced the importance of "precision" (seimitsusa) in Japan's criminal process, and this is especially conspicuous in capital trials. Before 2009, capital trials lasted for many months or years; trial sessions were held discontinuously, with one every few weeks or months, which gave all of the parties time to examine issues repeatedly while the trial inched toward the finish line. There were costs to that method of course-justice delayed can be justice denied, and some judges were transferred in mid-trialbut whatever its flaws, the previous system could not be accused of being insufficiently deliberate. In contrast, many capital trials in the lay judge system follow simple scripts, and many judges insist that trials stay "on schedule." This stress on efficiency may satisfy a Supreme Court that has instructed judges to finish lay judge trials efficiently, but surely concerns about convenience should not trump the imperative to administer capital punishment carefully. ${ }^{11}$

- $\underline{5}$. Vague Sentencing Standards: The "Nagayama standards" enumerated by Japan's Supreme Court in 1983 provide little guidance to the judges and lay judges who make life-and-death decisions. Many lay judges have noted this in post-trial press conferences, and many legal professionals regard the nine Nagayama factors as little more than a list of talking points for courts to consider. The Nagayama precedent also provides no direction about how to weigh the various factors, leaving life-and-death decision-making largely ungoverned by rules of law. ${ }^{12}$

${ }^{11}$ David T. Johnson, “Capital Punishment without Capital Trials in Japan's Lay Judge System", The Asia-Pacific Journal/Japan Focus, Vol. 7 (March 16, 2009), pp. 1-40, at https://apjjf.org/-David-T.-Johnson/3461/article.html.

${ }^{12}$ See, for example, Horikawa Keiko, Shikei no Kijun: 'Nagayama Saiban' ga Nokoshita Mono (Nihon Hyoronsha, 2009); and Nagata Kenji, Shikei Sentaku Kijun no Kenkyu (Kansai Daigaku Shuppanbu, 2010). 


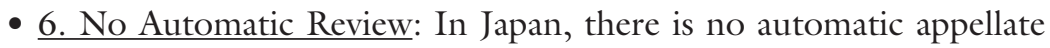
review for defendants who have been sentenced to death. In recent years, about one-third of all death sentences have been finalized without review by the Supreme Court. Most of these involve condemned inmates who have abandoned their appeals. ${ }^{13}$ This is not only careless, it also injects an element of arbitrariness in life-anddeath decision-making. Are people who volunteer to be executed somehow more deserving of death than those who insist on their own innocence? Moreover, half or more of death row inmates in Japan file requests for retrial in order to avoid execution, but these requests have no legal effect on the Minister of Justice's authority to order a hanging, and some condemned inmates are hanged despite a pending petition. The lack of mandatory review in Japan increases the risk of executing the innocent or the undeserving. This risk is magnified because no inmate on death row has received executive clemency in Japan since Ishii Kenjiro had his death sentence commuted to life imprisonment in 1975. Unlike Thailand, Malaysia, Indonesia, and other death penalty countries in Asia, executive clemency in capital cases in Japan is all but dead. ${ }^{14}$

- 7 . No Special Procedures for Selecting Lay Judges: In Japan, there are no special procedures for selecting lay judges to serve in murder trials. The defense and the prosecution each receive several rights to challenge prospective lay judges, but their use in the pretrial process is little more than a guessing game because the parties receive almost no information about the citizens who have been called to serve, and because the parties are not allowed to ask meaningful questions about the lay judge candidates during the selection procedure. Moreover, some lay judges are replaced while a trial is in session. In the capital trial of Ino Kazuo, a lay judge who asked many questions to the witnesses during trial was replaced

${ }^{13}$ The Death Penalty Project in association with the Centre for Prisoners' Rights, The Death Penalty in Japan (London: The Death Penalty Project, 2013), p. 27. By comparison, in recent years about 11 percent of death-sentenced prisoners in the United States hastened their own executions by abandoning their appeals. See Meredith Martin Rountree, "'I'll Make Them Shoot Me': Accounts of Death Row Prisoners Advocating for Execution", Law \& Society Review, Vol. 46, No. 3 (September 2012), pp. 589-622.

${ }^{14}$ Daniel Pascoe, Last Chance for Life: Clemency in Southeast Asian Death Penalty Cases (Oxford University Press, 2019). 
during the deliberations that followed the final trial session, but the Chief Judge did not take the trouble to inform the parties about the change, and the defense only discovered it after Ino was sentenced to death. In the capital trial of Tateyama Tatsumi, one lay judge slept repeatedly during the first eight trial sessions. Defense lawyers asked the Chief Judge to address this fundamental issue of fairness, but the Chief Judge (who also dozed during trial) refused to act until the day before the final trial session, when his hand was forced by a written petition from the defense that was supported by statements from several persons who were watching the trial with dismay over how much the lay judge slumbered during a murder trial. An American federal court judge (Reggie Walton) who warned jurors to stay awake during a trial said "I don't think God has given us a supernatural ability to sleep and listen at the same time." Some Japanese judges apparently have a different view. ${ }^{15}$

- 8. Law Is Not Explained in Open Court: In Japan, the presiding judge instructs (setsuji) lay judges about the law in the privacy of the deliberation room, not in open court where the prosecution, the defense, and trial watchers can assess these important directives. There is reason to worry that some judges present a pro-prosecution - and pro-death penalty - version of the law to lay judges. The failure to instruct lay judges in open court may also violate the defendant's Constitutional right to a public trial. In August 2010, a well-known defense lawyer (Takano Takashi) who was offering a training course in trial advocacy happened to eat lunch in a deliberation room used by Osaka District Court Chief

\footnotetext{
${ }^{15}$ Here is one passage from my own letter to the Chief Judge in Tateyama's trial, which the defense included in its petition to the court: "On the afternoon of June 14, I decided to count how many times Lay Judge 2 slept. From 1:15 to 1:45 PM, he fell asleep at least 33 times. Yes, that's right: 33 times in 30 minutes. Lay Judge 2 was sleeping almost constantly during this period of time (and at other times as well). I could have kept track for a longer period but, frankly, watching people sleep is not very interesting, so I stopped watching and counting at 1:45 PM. If Lay Judge 2 had been driving a car, he would have crashed." At the end of this letter I told the Chief Judge that "I also have noticed you sleeping during this trial, but because your sleeping is not as obvious or as frequent as that of Lay Judge 2, I will not request that you recuse yourself... But I do think it is a good idea for you to stay awake during murder trials. Do you agree with my view?" The Chief Judge did not reply to my letter.
} 
Judge Higuchi Hiroaki and his colleagues. On entering the room, Takano was initially pleased to see that "Rules for Criminal Trials" had been posted on a whiteboard, presumably to instruct lay judges who are amateurs in the law. But the more closely Takano read the rules, the more concerned he became. Incredibly, the whiteboard presented guidelines for convicting defendants but omitted language about when it is appropriate to acquit. In Takano's words, "I was amazed. I trembled a little. And I was indignant. You mean they'll even do shit like this?! This is what I cried out in my heart. If judges feel like it, they can use clever methods in the secrecy of the deliberation room to lead lay judges to their preferred conclusion without anyone noticing." 16

- 9. Death by Majority: In Japan, there is no requirement that all judges and lay judges agree that a death sentence is deserved, nor is there a requirement that a "super-majority" of seven or eight of the nine people on the panel agree before the ultimate penalty is imposed. A "mixed majority"-five votes, with at least one from a professional judge-is enough to condemn a person to death. This decision rule is hardly "cautious" about capital punishment. In all American jurisdictions that retain capital punishment, a death sentence can only be imposed if all 12 jurors agree that death is the appropriate sanction.

- 10. Passive Defense Lawyers: The assumption that death is not different also influences Japanese defense lawyers, mainly by inhibiting them from aggressively challenging the state's case for death. In some of the capital trials I have watched, defense lawyers were strikingly passive about contesting the state's case against the defendant, and they also were reluctant to directly challenge the propriety of capital punishment. ${ }^{17}$ Even more striking is the fact that for the past half-century, Japanese lawyers have almost never

${ }^{16}$ Quoted in David T. Johnson, "War in a Season of Slow Revolution: Defense Lawyers and Lay Judges in Japanese Criminal Justice", Asia-Pacific Journal/Japan Focus, Vol. 9 (June 29, 2011), pp. 1-11.

${ }^{17}$ David T. Johnson, "War in a Season of Slow Revolution: Defense Lawyers and Lay Judges in Japanese Criminal Justice", Asia-Pacific Journal/Japan Focus, Vol. 9 (June 29, 2011), pp. 1-11. 
challenged the constitutionality of capital punishment in general or hanging in particular. ${ }^{18}$ There are several reasons for this passivity, including the fact that Japan's Supreme Court has long been conservative. But in comparative perspective, the reluctance of Japanese lawyers to raise legal challenges that are routinely made in American jurisdictions seems to reflect tacit acceptance of the legitimacy of capital punishment. Until recently, Japanese defense lawyers rarely presented detailed evidence about the defendant's life history. Such presentations are often made in the sentencing stage of American capital trials. One key cause of the dramatic decline in American death sentences has been the ardent efforts of "mitigation specialists," who thoroughly investigate a capital defendant's "life story" and then tell it in detail to the jurors who decide whether to condemn the defendant to death. Japan has more than 30,000 lawyers but not a single mitigation specialist. The guidelines for paying state-appointed attorneys (kokusen bengonin), who do the bulk of criminal defense work in Japan, create little incentive to expend the arduous effort that is needed to construct a persuasive account of a defendant's life. The senior defense lawyer for Tateyama Tatsumi was paid no more for his work in that case than he was paid for work in other criminal cases where the stakes were much lower. That defense lawyer asked for a more appropriate fee, but his request was rejected by the court because there is no rule about capital cases in the fee guidelines. In this economic sense too, death is not different in Japan.

- 11. Prosecutors Can Appeal Non-death Decisions: In Japan, prosecutors are allowed two bites of the death penalty apple. If a District Court does not impose the ultimate penalty, prosecutors can ask an appellate court to reverse the original decision. This is what occurred in the case of a juvenile who was sentenced to death by the Hiroshima High Court in 2008 for killing a mother and her infant daughter in Hikari City nine years earlier. ${ }^{19}$ The right of

${ }^{18}$ As explained in Chapter 3, there is one significant exception: the murder trial of Takami Sunao in 2011, in which Japanese defense lawyers raised the issue of whether hanging is unconstitutionally cruel. In this case, the Osaka District Court held that hanging is constitutional.

${ }^{19}$ Masuda Michiko, Fukuda kun o Koroshite Nani ni Naru: Hikari-shi Boshi Satsugai Jiken no Kansei (Tokyo: Inshidentsu, 2009). 
prosecutors to appeal non-death sentences serves the value of consistency by allowing appellate courts to check whether like cases are being treated alike, but criminal trials at the appellate level tend to be far faster and rougher than the first-instance trials where oral testimony is heard. Here, too, one sees evidence of the assumption that capital cases do not require special procedures or protections.

- 12. Secrecy and Democracy: As will be explained in more detail in the next chapter, the administration of hanging in Japan is surrounded by secrecy and silence to an extent seldom seen in other death penalty nations. The main function of Japan's policy of secrecy is to protect the system of capital punishment-including the premise that death is not different-from outside scrutiny and criticism. There is also a problem of secrecy related to lay judges, who by law are not permitted to disclose "confidential" information about their experiences at trial. This coerced silence prevents the public from knowing and talking about how life-and-death decisions are made. The secrecy and silence that surround Japanese capital punishment belie official claims that it is administered in a manner that is cautious and careful.

\section{Two Ways Law Can FaIL}

In the years leading up to the start of Japan's lay judge system in 2009, more than 500 "mock trials" were held. The main objective was to anticipate the problems that might occur in the new trial system and to prepare for the complexities that inevitably accompany fundamental reforms of this kind. Despite this seemingly meticulous preparation, not a single mock trial was held in which prosecutors sought a sentence of death and a tribunal was asked to make a life-or-death decision. Here again is evidence of the assumption that death is not a different form of punishment in Japan.

The assumption that there is nothing special about capital cases is manifest at every level of Japanese adjudication, including the Supreme Court. I once asked a veteran journalist (Yamaguchi Susumu, the coauthor of a fine book $^{20}$ on Japan's Supreme Court) whether the

\footnotetext{
${ }^{20}$ Yamaguchi Susumu and Miyaji Yu, Saikosai no Anto: Shosuiken ga Jidai o Kiribiraku (Asahi, 2011).
} 
country's highest court considers death a "different" (tokubetsu) form of punishment. He said "yes," but when I asked how death is deemed different by the Supreme Court, he offered two replies, neither of which provides meaningful support for the assertion that the country's top court regards death as a special form of punishment. His first point was that before deciding whether to finalize (kakutei) a sentence of death, the Supreme Court gives defense lawyers an opportunity to make an oral argument-a privilege rarely granted to defense lawyers in other criminal cases. When I asked whether these oral arguments are little more than "empty rituals" (as many defense lawyers assert), Yamaguchi conceded that they are largely ceremonial, and that they seldom have a significant effect on the Justices' thinking. The second part of his answer was that the Justices on Japan's Supreme Court read the relevant documents "carefully" in capital cases. This response is revealing in two ways. For one thing, it suggests that Justices might not read records carefully in other kinds of cases. For another, trusting Justices to read the record "carefully" assumes there is no need for special procedures and protections in capital cases-much less for "super due process." I have studied criminal justice in Japan for the past thirty years, and I see no good reason to trust Justices on the Supreme Court (or any other judges) in this way. Like other scholars of Japanese criminal justice, I see many reasons to worry that judges will continue to defer to the prosecution, as they have done for decades. ${ }^{21}$

What happens to Supreme Court Justices in the United States and Japan as the result of hearing capital appeals? In a decision by the U.S. Supreme Court in 1972 (Furman v. Georgia), Justice Thurgood Marshall famously observed that if the American people were better informed about the reality of capital punishment, they would find it "shocking, unjust, and unacceptable." His hunch, which came to be known as the "Marshall hypothesis," has been the subject of much study, and its clearest confirmation comes from the death penalty conversions that many Justices have experienced while sitting on the U.S. Supreme

\footnotetext{
${ }^{21}$ See, for example, Hirano Ryuichi, "Diagnosis of the Current Code of Criminal Procedure", Law in Japan, Vol. 22 (1989), pp. 129-142; and Daniel H. Foote, "Policymaking by the Japanese Judiciary in the Criminal Justice Field," Hoshakaigaku, No. 72 (2010), pp. 6-45.
} 
Court. ${ }^{22}$ For example, in 1976 America's highest Court held (in Gregg v. Georgia) by a 7 to 2 majority that the new capital statutes enacted by states after the Furman decision had found capital punishment unconstitutional (because its arbitrary administration was like "being struck by lightning") were now constitutional. The Gregg decision restarted the American machinery of capital punishment that had been stopped by Furman four years before, and three of the seven votes in the majority were cast by Justices Powell, Stevens, and Stewart. By the end of their tenures on the bench-after many years of confronting the kinds of "capital error" described earlier in this chapter-these three Justices had come to conclude that it is impossible to administer the death penalty in a manner that is fair, just, and accurate. Their knowledge of the actual practice of capital punishment had converted them into opponents of the sanction. ${ }^{23}$

One leading scholar of American capital punishment has said that the actual practice of capital punishment in America is so inconsistent with the country's core legal values that "if you love the law, you must hate the death penalty." 24 Similarly, in 2009, the American Law Institute, the most prestigious law reform organization in the United States, withdrew its approval for the death penalty standards it had created in the Model Penal Code of 1963 because those standards had failed to provide adequate guidance for the juries who must decide which defendants should die. As another scholar observed,

Now that the creators of the modern system of death penalty sentencing have disowned that system, there is no support for distinguishing the current death penalty lottery from the lawless system that Furman condemned [in 1972]. The apparatus that the Supreme Court rushed to embrace in [the Gregg decision of] 1976 has been exposed as a conspicuous failure..$^{25}$

${ }^{22}$ Carol S. Steiker, "The Marshall Hypothesis Revisited", Howard Law Journal, Vol. 52, No. 3 (2009), pp. $522 \mathrm{ff}$.

${ }^{23}$ Evan J. Mandery, A Wild Justice: The Death and Resurrection of Capital Punishment in America (W. W. Norton, 2013), pp. 432-440.

${ }^{24}$ Austin Sarat, When the State Kills: Capital Punishment and the American Condition (Princeton University Press, 2001), p. 253.

${ }^{25}$ Franklin E. Zimring, "Pulling the Plug on Capital Punishment", The National Law Journal (December 7, 2009). 
In sum, here is the conclusion about capital punishment in the United States: lots of legal promises to administer the ultimate penalty fairly, justly, and accurately-and broken promises galore. Yet law can fail in more than one way. If the law of capital punishment in America fails to fulfill many of its promises, law in Japan fails by refusing to make many promises at all. This can be called a failure of aspiration and political will. ${ }^{26}$ The low ideals Japan has established for the administration of capital punishment help explain why Justices on its Supreme Court (unlike Justices on the U.S. Supreme Court) do not change their mind about this issue. When there are few requirements to satisfy before imposing a sentence of death, there is little room for frustration or failure, and there is no need to change one's mind. ${ }^{27}$

In the years to come, Japan could reform its approach to capital punishment in two ways. On the one hand, the courts and the country could start to take seriously the assertion its Supreme Court made seven decades ago - that "a single life weighs more than the entire earth." This road to reform would require significant changes in the Code of Criminal Procedure, but an even more fundamental requirement would be greater fidelity to existing law on the part of Japanese judges. At the top of my own list of necessary reforms are the introduction of a separate stage for sentencing in capital cases, and a decision rule requiring more than a mere majority in order to condemn a person to death.

In the second path to reform, Japan would renounce capital punishment on the grounds that it is impossible to administer it in a manner that is fair, just, and accurate. America has tried much harder than Japan to construct such a death penalty system, and the most reasonable conclusion to reach is that it has failed, badly. As U.S. Supreme Court Justice Harry Blackmun concluded in 1994,

\footnotetext{
${ }^{26}$ David T. Johnson, "The Death Penalty in Japan: Secrecy, Silence, and Salience", in Austin Sarat and Christian Boulanger, editors, The Cultural Lives of Capital Punishment: Comparative Perspectives (Stanford University Press, 2005), pp. 261-264.

${ }^{27}$ The other reason there are so many death penalty "conversions" among Justices on the U.S. Supreme Court and so few in Japan is that American Justices serve an average of 26 years, compared with just 6 years for Justices in Japan. The longer term of service means that American Justices encounter more capital cases and more capital error. See Andrew Cohen, "Why Don't [U.S.] Supreme Court Justices Ever Change Their Minds in Favor of the Death Penalty", The Atlantic, December 2013.
} 
From this day forward, I no longer shall tinker with the machinery of death. For more than 20 years I have endeavored...to develop...rules that would lend more than the mere appearance of fairness to the death penalty endeavor...Rather than continue to coddle the court's delusion that the desired level of fairness has been achieved...I feel...obligated simply to concede that the death penalty experiment has failed. It is virtually self-evident to me now that no combination of procedural rules or substantive regulations ever can save the death penalty from its inherent constitutional deficiencies... [T] his court eventually will conclude that the effort to eliminate arbitrariness while preserving fairness in the infliction of [death] is so plainly doomed to failure that it and the death penalty must be abandoned altogether...I may not live to see that day, but I have faith that eventually it will arrive. ${ }^{28}$

If Japan spends as long as America-almost half a century-trying to construct its own system of "super due process," I suppose the outcome could be a little less disappointing than Blackmun's lament suggests. Perhaps, but I doubt it. Comparative research should stretch our minds about what is possible and impossible. America's long experiment with capital punishment suggests that it may well be impossible to construct a system of capital justice that reaches only the rare right cases without also occasionally condemning the innocent or the undeserving. ${ }^{29}$ In my view, this is the pivotal issue in every country that still has capital punishment, and Japan would be foolish to ignore the abundant evidence from the United States. Whatever road Japan chooses to travel in the future, one thing is clear: the present presumption that death is not different is deeply problematic. It may turn out that Japan can do little better at administering capital punishment than it is doing now. But if the country continues to employ capital punishment, surely it should try.

\footnotetext{
${ }^{28}$ Callins $v$ Collins 510 US 1141 (1994).

${ }^{29}$ Scott Turow, Ultimate Punishment: A Lawyer's Reflections on Dealing with the Death Penalty (Farrar, Straus and Giroux, 2003), p. 114.
} 
Open Access This chapter is licensed under the terms of the Creative Commons Attribution-NonCommercial-NoDerivatives 4.0 International License (http://creativecommons.org/licenses/by-nc-nd/4.0/), which permits any noncommercial use, sharing, distribution and reproduction in any medium or format, as long as you give appropriate credit to the original author(s) and the source, provide a link to the Creative Commons license and indicate if you modified the licensed material. You do not have permission under this license to share adapted material derived from this chapter or parts of it.

The images or other third party material in this chapter are included in the chapter's Creative Commons license, unless indicated otherwise in a credit line to the material. If material is not included in the chapter's Creative Commons license and your intended use is not permitted by statutory regulation or exceeds the permitted use, you will need to obtain permission directly from the copyright holder.

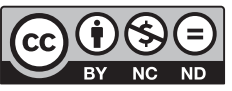

